\title{
PRE-PANDEMIC EARLY VIRAL PNEUMONIAS; COULD WE HAVE ENCOUNTERED COVID-19 BEFORE? ACCOMPANYING A DIAGNOSTIC MODEL
}

\author{
nevra güllüarslan ${ }^{1}$, figen eksert irkilata ${ }^{1}$, and aysu basak ozbalci ${ }^{2}$ \\ ${ }^{1}$ Samsun Education and Research Hospital \\ ${ }^{2}$ Ondokuz Mayis Universitesi
}

April 30, 2021

\begin{abstract}
Introduction COVID-19 shows similar clinical and radiological findings with other viral pneumonias. This study designed to explore the likelihood of the existence of COVID-19 pneumonia in our country before March 11th, date of first official COVID-19 case detected in Turkey, by using a diagnostic model designed with radiologic and laboratory findings. Materials and Methods 273 patients were aggrouped according to hospitalization date, naso-oropharyngeal swab PCR results. Thoracic tomographies, C-reactive protein (CRP), leukocyte, lymphocyte, monocyte, eosinophil, platelet values of all patients were evaluated. Results Laboratory findings of lymphocyte, eosinophil counts $(\mathrm{p}<0.05)$ were significantly low; radiologic findings of round opacity, cobblestone, nodüle, subpleural line were significant in COVID-19 group ( $<<0.05)$. 'Round opacity', 'subpleural line', 'nodule', 'lymphocyte' variables were found to be statistically significant for final model ( $<<0.05)$. COVID-19 diagnosis possibility; increases $302.9 \%$ by 'round opacity', $355.6 \%$ by 'subpleural lines'; and decreases $59.1 \%$ by 'nodule' presence, $31.7 \%$ by one unit increase in lymphocyte level. Based on final model; 49.3\% of the participants before 11 March 2020 were predicted to be positive for COVID-19. Conclusion According to these findings, we can say that COVID-19 patients existed before March 11th, 2020 in Turkey, for the first time. Also subpleural lines, presence of cobblestone, round opacity appearances and absence of nodules on tomography, and the presence of lymphopenia and eosinopenia in the cell count can also be used to support the diagnosis of COVID pneumonia.
\end{abstract}

\section{Hosted file}

main text.pdf available at https://authorea.com/users/411094/articles/520236-pre-pandemicearly-viral-pneumonias-could-we-have-encountered-covid-19-before-accompanying-adiagnostic-model

\section{Hosted file}

tables.pdf available at https://authorea.com/users/411094/articles/520236-pre-pandemicearly-viral-pneumonias-could-we-have-encountered-covid-19-before-accompanying-adiagnostic-model 